\begin{tabular}{cc|c}
\hline Tar. Bil. Der. & Tarım Bilimleri Dergisi & Journal of Agricultural Sciences \\
& $\begin{array}{c}\text { Dergi web sayfası: } \\
\text { www.agri.ankara.edu.tr/dergi }\end{array}$ & Journal homepage: \\
& www.agri.ankara.edu.tr/journal
\end{tabular}

\title{
Effects of Ozone Treatment on the Degradation and Toxicity of Several Pesticides in Different Groups
}

\author{
Yakup Sedat VELIOGLU ${ }^{a}$, Şeyda FÍKİRDEŞíCI-ERGEN ${ }^{b}$, Pelin AKSU', Ahmet ALTINDAĞ ${ }^{\mathrm{b}}$ \\ aAnkara University, Faculty of Engineering, Department of Food Engineering, Gölbaşı, Ankara, TURKEY \\ ${ }^{\boldsymbol{b}}$ Ankara University, Faculty of Science, Department of Biology, Tandoğan, Ankara, TURKEY \\ ${ }^{c}$ Plant Protection Central Research Institute, Yenimahalle, Ankara, TURKEY
}

\section{ARTICLE INFO}

Research Article DOI: 10.15832/ankutbd.446448

Corresponding Author: Yakup Sedat VELIOGLU, E-mail: velioglu@ankara.edu.tr, Tel: +90 (312) 20333 00/3619

Received: 04 March 2016, Received in Revised Form: 26 October 2017, Accepted: 04 November 2017

\begin{abstract}
The effects of ozone treatment on the degradation and toxicity of nine pesticides were determined with different chromatographic techniques, using bubbled ozone and distilled water and two different buffer solutions as test media. The toxicity experiments were performed using Daphnia magna, a cladoceran fresh water flea. The results revealed that thiacloprid and acetamiprid can only be degraded by ozonation to a limited extent (max 2.6\%). The other seven pesticides were successfully degraded by ozone. The degradation rates (\%) were found to be $93,99,95,99,87,98$, and 85 for fenazaquin, lambda cyhalothrin, azoxystrobin, chlorpyrifos, spiromesifen, clothianidin and thiamethoxam, respectively, after 5 minutes of ozone treatment in distilled water. The ozone treatment yielded reduced toxicity in fenazaquin, lambda cyhalothrin, azoxystrobin, chlorpyrifos and spiromesifen. However, the degradation products of clothianidin and thiamethoxam were found to be more toxic than the pesticide itself. In general, the use of buffer solutions has no significant effect on pesticide degradation compared to water as an ozonation medium.
\end{abstract}

Keywords: Ozonation; Daphnia magna; Insecticide; Fungicide; Transformation; Toxic

\section{Ozonlama İşleminin Farklı Gruplardaki Pestisitlerin Parçalanma ve Toksisitesi Üzerine Etkileri}

\section{ESER BILGIISİ}

Araştırma Makalesi

Sorumlu Yazar: Yakup Sedat VELIOGLU, E-posta: velioglu@ankara.edu.tr, Tel: +90 (312) 203 33 00/3619

Geliş Tarihi: 04 Mart 2016, Düzeltmelerin Gelişi: 26 Ekim 2017, Kabul: 04 Kasım 2017

ÖZET

Ozonlama işleminin dokuz farklı pestisitin parçalanma ve toksisitesi üzerine etkileri farklı kromatografik tekniklerle incelenmiştir. Çalışmada ozon gazı baloncuk yöntemiyle su ve iki farklı tampon çözelti ortamında uygulanmıştır. Toksisite denemelerinde Cladocera takımında yer alan su piresi (Daphnia magna) kullanılmıştır. Bulgulara göre, ozonlama ile thiacloprid ve acetamiprid çok sınırlı bir şekilde (en çok \% 2.6) parçalanabilirken diğer yedi pestisit 
çok iyi parçalanmıştır. Saf suda 5 dakikalık ozonlama uygulamasıyla fenazaquin, lambda cyhalothrin, azoxystrobin, chlorpyrifos, spiromesifen, clothianidin ve thiamethoxamın parçalanma oranları (\%) sırasıyla 93, 99, 95, 99, 87, 98 ve 85 olarak bulunmuştur. Ozonlama işlemi fenazaquin, lambda cyhalothrin, azoxystrobin, chlorpyrifos ve spiromesifende toksisitenin azalmasını sağlarken clothianidin ve thiamethoxamın parçalanma ürünlerinin toksisitesi başlangıç bileşiğinden daha fazla bulunmuştur. Genel olarak tampon çözelti kullanımı pestisitlerin parçalanmasında suya göre önemli bir farklılık oluşturmamıştır.

Anahtar Kelimeler: Ozon; Daphnia magna; İnsektisit; Fungusit; Bozunma; Toksik

(C) Ankara Üniversitesi Ziraat Fakültesi

\section{Introduction}

Pesticides are widely used pre-and post-harvest to meet the nutritional needs of a growing population, thus reducing product losses due to diseases, pests and weeds. Although pesticides have many benefits, their unconscious or intensive use during cultivation or storage has resulted in the presence of residual compounds or its degradation products in food products. In addition to contaminating food products, pesticide residues also create serious problems in the soil, on the ground, in surface water and in the air, therefore creating public and regulatory concern (Albanis et al 1998; Horvitz \& Cantalejo 2014).

Pesticide residues on food products can be reduced through various methods, including washing with water or soaking in several chemical solutions, e.g. chlorine, ozone, hydrogen peroxide, salts, and detergents. The degradation mechanism of pesticides relies on oxidation, hydrolysis, reduction, photolysis, metabolism, temperature and pH (Bajwa \& Sandhu 2014). Chemical oxidation is one of the most promising applications for destroying pesticides, chemical residues, and mycotoxins, converting non-biodegradable organic materials into biodegradable forms and reducing the microbial load of food products or water. Ozonation is considered to be one of the best variations of chemical oxidation. Ozone can be combined with hydrogen peroxide and UV radiation, which are other hydroxyl radical-based advanced oxidation techniques (Karaca \& Velioglu 2007; Karaca et al 2010). The advantages of ozone as an oxidant are that it provides oxygen to the oxidizing medium and that no harmful substances are formed in this environment. Ozone is also used efficiently for industrial, domestic and drinking water purification (Wu et al 2007).

A number of studies indicate that some pesticides are successfully degraded with ozone in aqueous solutions. Azinphos-methyl, captan and formenate can be degraded by a combination of ozone and chlorine. Dipping apples into $0.25 \mathrm{mg} \mathrm{kg}^{-1}$ ozonated water reduced the contents of these three pesticides by $75 \%, 72 \%$ and $46 \%$, respectively. The maximum degradation rate of azinphos-methyl was $83 \%$ in a model system (Ong et al 1996). Hwang et al (2001) reported that mancozeb and ethylenethiourea (ETU) in apples can be decreased by 56$97 \%$ with $1-10 \mathrm{mg} \mathrm{kg}^{-1}$ ozone, and the ETU was completely removed with 1 and $3 \mathrm{mg} \mathrm{kg}^{-1}$ ozone. In another study it was shown that an ozone wash with $3 \mathrm{mg} \mathrm{kg}^{-1}$ ozone was the most effective treatment for mancozeb and ETU removal. The authors also indicated that the degradation byproducts of some organophosphate pesticides might be more toxic than the initial compound (Hwang et al 2002). Wu et al (2007) reported that $1.4 \mathrm{mg}$ $\mathrm{kg}^{-1}$ ozone was effective to degrade $60-99 \%$ of $0.1 \mathrm{mg} \mathrm{kg}^{-1}$ diazinon, parathion, methyl-parathion and cypermethrin within $30 \mathrm{~min}$. The degradation rate was highly dependent on the dissolved ozone, and the maximum removal was detected at $15-20$ ${ }^{\circ} \mathrm{C}$. Kim et al (2000) treated soybeans with $0.3 \mathrm{mg}$ $\mathrm{kg}^{-1}$ ozonated water for $30 \mathrm{~min}$ and determined the changes on the carbendazim, captan, diazinon, fenthim, dichlorvos and chlorpyriphos residues. The ozone treatments destroyed residues better than water itself. A treatment temperature of $30{ }^{\circ} \mathrm{C}$ was found to be more effective than other tested 
temperatures on the fenitrothion degradation by ozone in lettuce and cherry tomatoes, with relatively little effect on crop quality (Ikeura et al 2013). The ozone $/ \mathrm{UV} / \mathrm{TiO}_{2}$ combination in tea leaves reduced the cypermethrin and malathion residues by $80 \%$ and $78 \%$, respectively (Lin et al 2012). Five minutes of ozonation reduced the tetradifon residue $98.6 \%$ in lemons and $94.2 \%$ in grapefruits (Kusvuran et al 2012). The ozone flow at $500 \mathrm{mg} \mathrm{kg}^{-1}$ reduced chlorfluazuron and chlorothalonil residues $75 \%$ and $77 \%$, respectively, in vegetables (Chen et al 2013). The storage of table grapes in an ozone atmosphere accelerated fenhexamid, cyprodinil and pyrimethanilin degradation (Karaca et al 2012). In olives ozonated water wash for 5 min reduced chlorpyrifos, beta-cyfluthrin, alpha-cypermethrin and imidacloprid contents by $38 \%, 50 \%, 55 \%$ and $61 \%$, respectively (Kırış \& Velioglu 2016).

Daphnia magna, a cladoceran fresh water flea, is an important bio indicator (Martins et al 2007) used in the evaluation of the toxicity levels of pesticides and pesticide degradation products in aquatic ecosystems (Sanchez-Bayo \& Goka 2006). During the ozonation process, degradation products are formed but chemical compositions cannot be identified. In vivo and in vitro toxicity tests are important to specify the effects of degradation products on human and animal health.

Previous studies have demonstrated that most pesticides can be degraded with ozone treatment. However, ozonation may produce by-products caused by the reaction between ozone and the pesticide and, as shown in this paper, degradation products are formed but their chemical structure cannot be easily identified and this product can be more toxic than the initial product. The aim of this study is to reveal the effects of ozone treatment on the degradation and toxicity of nine pesticides belonging to six different groups.

\section{Material and Methods}

Names, sources, functions, sub-groups, purities, stock solution concentrations (approx. $10000 \mathrm{mg}$ $\mathrm{kg}^{-1}$ ), open structures and the chromatographic method of tested pesticides were given in Table 1. Test solutions were freshly prepared by dissolving the pesticides with a few drops of dimethylsulfoxide (fenazaquin, clothianidin, thiacloprid and acetamiprid) or acetonitrile (lambda cyhalothrin, azoxystrobin, chlorpyrifos, spiromesifen and thiamethoxam) and then diluting the solution to its final volume using ASTM Type 2 high-purity water (TKA Scientific, Niederelbert, Germany) and citrate-buffer solutions $\left(10^{-3} \mathrm{M}\right.$ at $\mathrm{pH} 5.5$ and $\mathrm{pH}$ 6.5). Because of the high dilution rate and the use of control solutions in the toxicity experiments, the use of acetonitrile did not result in any problems. Each test solution of pesticides was diluted to concentration of $10 \mathrm{mg} \mathrm{kg}^{-1}$ from the stock solutions.

\subsection{Ozonation apparatus and procedure}

Ozone was produced from air using a corona discharge ozone generator (OG-20, Opal, Turkey), with a production capacity of $20 \mathrm{~g} \mathrm{~h}^{-1}$ of ozone. The pesticide solutions were ozonated in $30 \mathrm{~mL}$ Falcon test tubes; alternatively, in cases where large volumes of solvent were needed because of a pesticide's low toxicity, $250 \mathrm{~mL}$ glass bottles (Isolab, Boro 3.3, Wertheim, Germany) were used for the pesticide degradation and toxicity tests. Tube (or bottle) caps had a hole in the centre, allowing a tube to be passed through. The tubing was connected to a stainless steel solvent inlet filter $(10 \mu \mathrm{m}$ pore size $)$ (Fisher Scientific, Schwerte, Germany). The filter was kept at the bottom of the tube (or bottle) during the ozonation process, allowing efficient ozone diffusion in the liquid phase. The caps also had 6-8 other small holes around the centre hole to permit the release of ozone. The ozone flow was adjusted to be $600 \mathrm{~mL} \mathrm{~min}{ }^{-1}$ with a "Riteflow" flowmeter, size 2, (Bel-Art Products, Pequannock, USA). All ozonation processes were performed at $15^{\circ} \mathrm{C}$, using a cooling water bath (Polyscience, USA). After the ozonation was complete, the reaction was stopped using $10 \mu \mathrm{L}$ of $5.2 \mathrm{~g} \mathrm{~L}^{-1}$ Difco neutralizing buffer (Cat. No. 236210, Becton, Dickinson and Sparks, USA). All experiments were conducted in triplicate in a fume hood. 
Table 1- Chemical structures and properties of the studied pesticides

\begin{tabular}{|c|c|c|c|c|}
\hline $\begin{array}{l}\text { Active } \\
\text { substancel } \\
\text { sources }\end{array}$ & $\begin{array}{l}\text { Function/ } \\
\text { sub-group }\end{array}$ & $\begin{array}{l}\text { Purity }(\%) / \text { stock } \\
\text { solution used } \\
\left(m g \mathrm{~kg}^{-1}\right)\end{array}$ & Open structure & $\begin{array}{l}\text { Analysis } \\
\text { method }\end{array}$ \\
\hline $\begin{array}{l}\text { Thiacloprid/ } \\
\text { BAYER }\end{array}$ & $\begin{array}{l}\text { Insecticide/ } \\
\text { neonicotinoid }\end{array}$ & $\begin{array}{l}99.7 / \\
10000\end{array}$ & & HPLC \\
\hline $\begin{array}{l}\text { Thiamethoxam/ } \\
\text { SYNGENTA }\end{array}$ & $\begin{array}{l}\text { Insecticide/ } \\
\text { neonicotinoid }\end{array}$ & $\begin{array}{c}99.7 / \\
20000\end{array}$ & & HPLC \\
\hline $\begin{array}{l}\text { Clothianidin/ } \\
\text { BAYER }\end{array}$ & $\begin{array}{l}\text { Insecticide/ } \\
\text { neonicotinoid }\end{array}$ & $\begin{array}{l}99.7 / \\
10000\end{array}$ & & HPLC \\
\hline $\begin{array}{l}\text { Acetamiprid/ } \\
\text { AGRO-BEST }\end{array}$ & $\begin{array}{l}\text { Insecticide } \\
\text { neonicotinoid }\end{array}$ & $\begin{array}{l}99.0 / \\
10000\end{array}$ & & HPLC \\
\hline
\end{tabular}

$\begin{array}{llll}\text { Fenazaquin/ } & \text { Acaricide/METI } & 96.0 / & 10000 \\ \text { AGRO-BEST } & & \text { HPLC }\end{array}$

Lambda

cyhalothrin/

DR. EHRENS-

TORFER
Insecticide/

Pyrethroid

$98.0 /$

10000

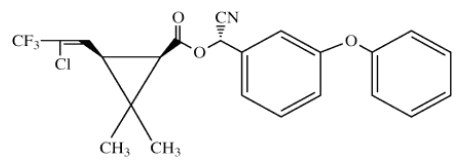

$\mathrm{GC} / \mu \mathrm{ECD}$

GC/MS

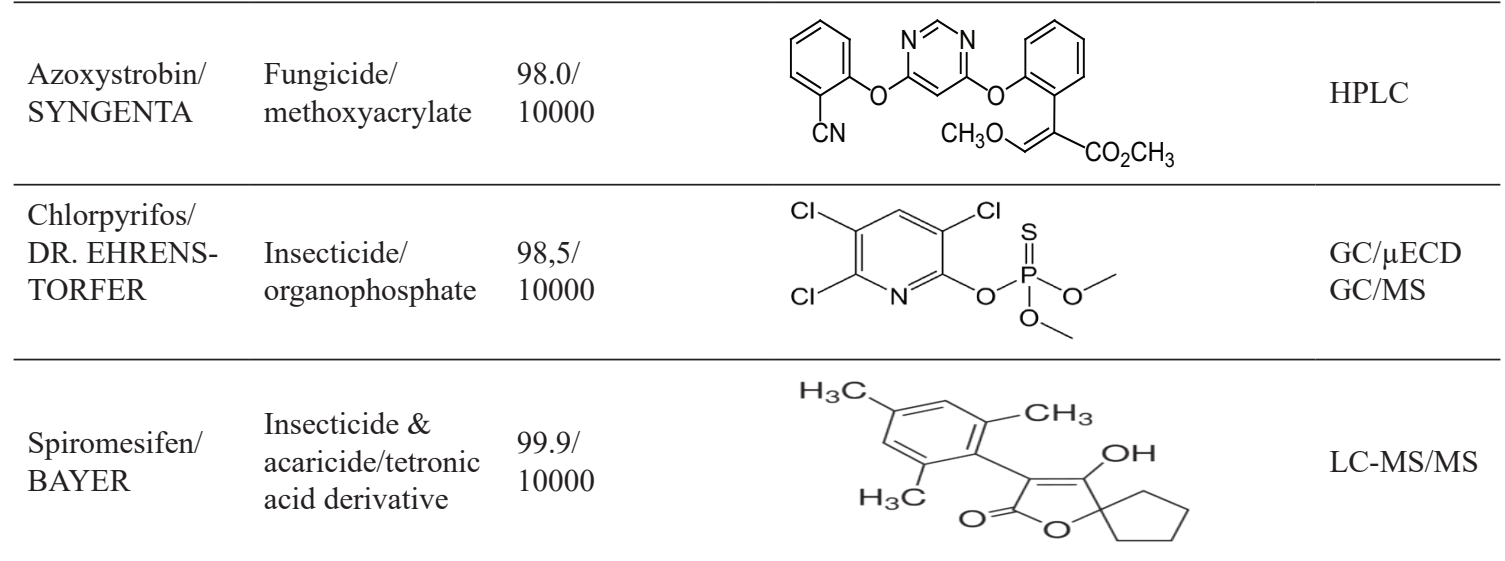




\subsection{Analysis of pesticides}

The concentration of thiacloprid, acetamiprid, clothianidin and thiamethoxam measured with HPLC (Shimadzu, Japan) consisted of a LCX-20AD pump, SPD-M20A diode array detector (DAD), DGU 20A5-E degasser, and a CTO-10ASVP column oven. The working temperature and injection volume were $25^{\circ} \mathrm{C}$ and $20 \mu \mathrm{L}$, respectively, and the detection wavelength was $242 \mathrm{~nm}$ for thiacloprid and acetamiprid, $267 \mathrm{~nm}$ for clothianidin and 252 $\mathrm{nm}$ for thiamethoxam. A mixture of methanol water (50:50 $\mathrm{v} \mathrm{v}^{-1}$ for thiacloprid and acetamiprid; 60:40 $\mathrm{V} \mathrm{V}^{-1}$ for clothianidin and thiamethoxam) at a flow rate of $0.5 \mathrm{~mL} \mathrm{~min}^{-1}$ was used as the mobile phase under isocratic conditions. Samples were filtered through a $0.45 \mu \mathrm{m}$ PTFE filter (Millipore, MillexLCR) and injected directly. The concentrations of fenazaquin and azoxystrobin were measured using an Agilent (1100) HPLC system that consisted of a gradient elution pump and a DAD detector. The working temperature, injection volume and detection wavelengths were $25{ }^{\circ} \mathrm{C}, 20 \mu \mathrm{L}$, and $216 \mathrm{~nm}$ (fenazaquin) and $254 \mathrm{~nm}$ (azoxystrobin), respectively. A mixture of acetonitrile water (90:10 $\mathrm{v} \mathrm{v}^{-1}$ for fenazaquin; 37:63 $\mathrm{v} \mathrm{v}^{-1}$ for azoxystrobin) at a flow rate of $1.0 \mathrm{~mL} \mathrm{~min}^{-1}$ was used as the mobile phase under isocratic conditions. A Nucleosil (Phenomenex, Torrance, CA, USA) or Inertsil (GL Sciences, Japan) column (C18, $5 \mu \mathrm{m} ; 250 \mathrm{~mm} \times 4.6$ $\mathrm{mm}$ ) was used in the HPLC analyses. The reductions in the pesticide contents were calculated from the reduction of the peak areas after ozone treatments.

The concentrations of lambda cyhalothrin and chlorpyrifos were measured using a GC/ $\mu \mathrm{ECD}$. The Agilent (6890N GC) system consisted of an Agilent 6890 series auto sampler and a fused-silica capillary column HP-5 (30 m x $0.25 \mathrm{~mm}$ ID and $0.25 \mu \mathrm{m}$ film thickness) (Chrom Tech., Apple Valley, MN, USA). The split ratio was 50:1 and the carrier gas was $99.999 \%$ helium at $1 \mathrm{~mL} \mathrm{~min}{ }^{-1}$. The working temperature, detector temperature and injection volume were $250{ }^{\circ} \mathrm{C}, 300{ }^{\circ} \mathrm{C}$ and $1 \mu \mathrm{L}$, respectively. The column program was $70{ }^{\circ} \mathrm{C}(2 \mathrm{~min})$ to $280{ }^{\circ} \mathrm{C}$

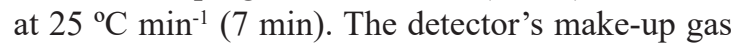
was nitrogen $(99.999 \%)$ at $59 \mathrm{~mL} \mathrm{~min}{ }^{-1}$. The total analysis time was 17.40 min. For the GC analyses, samples were treated as follows: $10 \mathrm{~g}$ of sample was weighed into $50 \mathrm{~mL}$ centrifuge tube and $10 \mathrm{~mL}$ of acetonitrile, $4 \mathrm{~g}$ of anhydrous $\mathrm{MgSO}_{4}$ and $0.5 \mathrm{~g}$ of $\mathrm{NaCl}$ were added. Tube was shaken immediately for $2 \mathrm{~min}$. The extract was than centrifuged at 5000 rpm for $5 \mathrm{~min}$. A $1 \mu \mathrm{L}$ aliquot of supernatant was then injected into the GC/ $\mu \mathrm{ECD}$. The concentration of the spiromesifen was measured under isocratic conditions using LC-MS/MS equipment (Waters, TQD Triple Quadrupole Mass Spectrometer) and an Acquity UPLC BEH column $(\mathrm{C} 18,2.1 \times 100 \mathrm{~mm} \times$ $1.7 \mu \mathrm{m}$ ) (Waters, USA). The working conditions are shown in Table 2.

\subsection{Toxicity tests}

A total of 10 neonates (age $<24 \mathrm{~h}$ ) attained from the original culture were exposed to pesticide. There was no feeding during the test. The toxicity was expressed by the median lethal concentration, that is, the dose required to kill half of the daphnid members of $\mathrm{LC}_{50}$ (median lethal concentration) exposure. After $24 \mathrm{~h}-48 \mathrm{~h}$ the live D. magna were counted. Exposure to the different concentrations was carried out in triplicate. $\mathrm{LC}_{50}$ values were calculated using the regression line obtained by plotting the concentration against the death percentage on a probit scale, and the results were assessed with probit analysis (SPSS 22.0v.). (Fikirdeşici et al 2012). A total of 10 neonates (age $<24 \mathrm{~h}$ ) obtained from the original culture were exposed to five different concentrations of clothianidin (120000, 125000, 130000, 135000, $\left.140000 \mu \mathrm{g} \mathrm{L}^{-1}\right)$; thiamethoxam (70000, 110000, 150000, 190000, $\left.230000 \mu \mathrm{g} \mathrm{L}^{-1}\right)$; fenazaquin (1, 5, 9, 13, $\left.17 \mu \mathrm{g} \mathrm{L}^{-1}\right)$; lambda cyhalothrin $(0.001,0.005$, $\left.0.009,0.013,0.017 \mu \mathrm{g} \mathrm{L}^{-1}\right)$; azoxystrobin $(50,100$, 150, 200, $\left.250 \mu \mathrm{g} \mathrm{L}^{-1}\right)$; chlorpyrifos $(0.3,0.6,0.9$, $\left.1.2,1.5 \mu \mathrm{g} \mathrm{L}^{-1}\right)$; and spiromesifen $(1,1.2,1.4,1.6$, $\left.1.8 \mu \mathrm{g} \mathrm{L}^{-1}\right)$.

\subsection{Statistical analysis}

Experimental results were expressed as the means \pm standard errors. Two-way ANOVA was performed using SPSS for Windows (ver. 10.1, USA). Significant differences between the means 
Table 2- LS-MS/MS working conditions for the determination of spiromesifen

\begin{tabular}{|c|c|c|c|c|c|c|c|}
\hline Equipment/ & \multicolumn{7}{|c|}{ Water, Model TQD Triple Quadrupole Mass Spectrometer } \\
\hline Column & \multicolumn{7}{|c|}{ Acquity UPLC BEH C18 2.1 x $100 \mathrm{~mm}$ x $1.7 \mu \mathrm{m}$} \\
\hline Mobil phases & \multicolumn{7}{|c|}{ A1: $2 \mathrm{mM}$ ammonium format containing $\mathrm{MeOH}$ : water (10:90) } \\
\hline & \multicolumn{7}{|c|}{ B1: 2 mM ammonium format containing $\mathrm{MeOH}$ : water (95:5) } \\
\hline & \multicolumn{7}{|c|}{ A2: MeOH: water (50:50) B2: MeOH: acetonitrile (50:50) } \\
\hline & \multicolumn{7}{|c|}{ Weak needle wash and seal wash: water: $\mathrm{MeOH}(95: 5)$} \\
\hline & \multicolumn{7}{|c|}{ Strong needle wash: $\mathrm{MeOH}$} \\
\hline & \multicolumn{7}{|c|}{ Gradient } \\
\hline \multirow[t]{8}{*}{ Inlet programme: } & $\underline{\text { Time }}$ & Flow & $\% \mathrm{~A}$ & $\% \mathrm{~B}$ & & & \\
\hline & - & 0.45 & 90 & 10 & & & \\
\hline & 1.00 & 0.45 & 90 & 10 & & & \\
\hline & 12.00 & 0.45 & 5 & 95 & & & \\
\hline & 13.00 & 0.45 & 5 & 95 & & & \\
\hline & 13.05 & 0.45 & 90 & 10 & & & \\
\hline & 16.00 & 0.45 & 90 & 10 & & & \\
\hline & \multicolumn{7}{|c|}{ Seal wash: 5 min, run time: 15 min, max pressure: $1500 \mathrm{psi}$} \\
\hline \multirow[t]{3}{*}{ Autosampler } & \multicolumn{7}{|c|}{ Full loop } \\
\hline & \multicolumn{7}{|c|}{ Wash solvents: $600 \mu \mathrm{L}$ weak, $300 \mu \mathrm{L}$ strong } \\
\hline & \multicolumn{7}{|c|}{ Column temp.: $50^{\circ} \mathrm{C}$ Sample temp.: $10^{\circ} \mathrm{C}$} \\
\hline Injection volume: & \multicolumn{7}{|l|}{$20 \mu \mathrm{L}$} \\
\hline \multirow[t]{3}{*}{ Tune parameters: } & \multicolumn{7}{|c|}{$\begin{array}{l}\text { Polarity: ES+ or ES-; capillary }(\mathrm{kV}): 1.00 \text {; cone }(\mathrm{V}) \text { : compound dependent; extractor }(\mathrm{V}): 3 \text {; } \\
\text { RF lens (V): } 0.1 \text {; source temp.: } 130^{\circ} \mathrm{C}\end{array}$} \\
\hline & \multirow{2}{*}{\multicolumn{7}{|c|}{$\begin{array}{l}\text { Desolvation temp.: } 400{ }^{\circ} \mathrm{C} \text {; cone gas flow }\left(\mathrm{L} \mathrm{h}^{-1}\right): 50 \text {; desolvation gas flow }\left(\mathrm{L} \mathrm{h}^{-1}\right): 900 \text {; } \mathrm{LM} 1 \\
\text { resolution: 14; HM1 resolution: 14; ion energy 1: } 0,5 \text {; entrance: } 50 \text {; collision: compound } \\
\text { dependent; exit: } 50 \\
\text { LM2 resolution: } 14 ; \mathrm{HM} 2 \text { resolution: } 14 \text {; ion energy } 2: 0.8 \text {; gain: } 1.0 \text {; multiplier (V): } 650\end{array}$}} \\
\hline & & & & & & & \\
\hline \multicolumn{8}{|c|}{ Spiromesifen MRM parameters } \\
\hline \multirow[t]{2}{*}{$\begin{array}{l}\text { Spiromesifen } \\
(\mathrm{ESI}+)\end{array}$} & $\begin{array}{l}\text { Parent } \\
(\mathrm{m} / \mathrm{z})\end{array}$ & & hter1 & $\begin{array}{l}\text { Daughter2 } \\
(\mathrm{m} / \mathrm{z})\end{array}$ & $\begin{array}{l}\text { Cone } \\
\text { (V) }\end{array}$ & $\begin{array}{l}\text { Collision1 } \\
\text { (V) }\end{array}$ & $\begin{array}{l}\text { Collision2 } \\
\text { (V) }\end{array}$ \\
\hline & 371.20 & & & 273.15 & & 24 & 8 \\
\hline
\end{tabular}

were determined using Duncan's multiple range test. Differences were considered significant at $\mathrm{P}<0.05$. All of the experiments were performed in triplicate.

\section{Results and Discussion}

\subsection{Thiacloprid and acetamiprid degradation by ozone treatment}

The results revealed that thiacloprid degradation with ozone was quite difficult and the degradation rate was never more than $2.6 \%$ at 10 minutes of treatment time
(Table 3). To determine the effects of unpractically longer treatment times, the samples were ozonated for 20 minutes and the degradation rate only reached $5 \%$ (not shown in the table). Buffer use yielded a nonsignificant degradation rate $(\mathrm{P}>0.05)$ as compared to treatment in water. Because the thiacloprid degradation was much lower than the expected level (20-25\%) it was, therefore, not subjected to toxicity tests.

The acetamiprid degradation was found to be even more difficult, and a very long treatment time (20 minutes) yielded only $0.22 \%$ degradation in 
Table 3- Effects of ozonation time and media on the degradation (\%) of pesticides ${ }^{a}$ (initial pesticide concentration and volume in ozonation media $10 \mathrm{mg} \mathrm{kg}^{-1}$ and $20 \mathrm{~mL}$, respectively)

\begin{tabular}{|c|c|c|c|c|}
\hline \multirow[b]{2}{*}{ Pesticides } & \multirow{2}{*}{$\begin{array}{l}\text { Ozonation } \\
\text { time (min) }\end{array}$} & \multicolumn{3}{|c|}{ Ozonation media } \\
\hline & & Water & Buffer (pH 5.5) & Buffer (pH 6.5) \\
\hline \multirow{2}{*}{ Fenazaquin } & 2 & $91.26 \pm 0.61^{\mathrm{Aa}}$ & $94.56 \pm 0.18^{\mathrm{Aa}}$ & $93.67 \pm 0.12^{\mathrm{Aa}}$ \\
\hline & 5 & $93.38 \pm 0.21^{\mathrm{Aa}}$ & $96.46 \pm 0.29^{\mathrm{Aa}}$ & $95.70 \pm 0.32^{\mathrm{Aa}}$ \\
\hline \multirow{3}{*}{ Lambda cyhalothrin } & 1 & $79.21 \pm 1.74^{\mathrm{Ab}}$ & $82.22 \pm 0.03^{\mathrm{Ab}}$ & $73.21 \pm 2.40^{\mathrm{Aa}}$ \\
\hline & 2 & $97.00 \pm 0.39^{\mathrm{Ba}}$ & $95.80 \pm 0.37^{\mathrm{Ba}}$ & $94.93 \pm 0.05^{\mathrm{Ba}}$ \\
\hline & 5 & $98.62 \pm 0.62^{\mathrm{Ba}}$ & $99.19 \pm 0.16^{\mathrm{Ba}}$ & $98.61 \pm 0.1^{\mathrm{Ca}}$ \\
\hline \multirow{3}{*}{ Azoxystrobin } & 2 & $93.71 \pm 0.67^{\mathrm{Ac}}$ & $89.76 \pm 0.48^{\mathrm{Ab}}$ & $95.43 \pm 0.21^{\mathrm{Aa}}$ \\
\hline & 5 & $94.68 \pm 0.17^{\mathrm{Ab}}$ & $95.02 \pm 0.33^{\mathrm{Bb}}$ & $97.76 \pm 0.15^{\mathrm{Ba}}$ \\
\hline & 10 & $98.82 \pm 0.14^{\mathrm{Ba}}$ & $98.19 \pm 0.28^{\mathrm{Ca}}$ & $99.24 \pm 0.04^{\mathrm{Ca}}$ \\
\hline \multirow{3}{*}{ Chlorpyrifos } & 2 & $93.25 \pm 0.15^{\mathrm{Ac}}$ & $67.05 \pm 1.63^{\mathrm{Ab}}$ & $24.90 \pm 1.84^{\mathrm{Aa}}$ \\
\hline & 5 & $98.96 \pm 0.04^{\mathrm{Bc}}$ & $72.14 \pm 0.67^{\mathrm{Bb}}$ & $96.85 \pm 0.32^{\mathrm{Ba}}$ \\
\hline & 10 & $99.00 \pm 0.09^{\mathrm{Bb}}$ & $86.99 \pm 0.29^{\mathrm{Ca}}$ & $98.70 \pm 0.24^{\mathrm{Bb}}$ \\
\hline \multirow{3}{*}{ Spiromesifen } & 2 & $76.70 \pm 0.13^{\mathrm{Aa}}$ & $94.05 \pm 0.02^{\mathrm{Ab}}$ & $78.49 \pm 0.20^{\mathrm{Aa}}$ \\
\hline & 5 & $86.93 \pm 0.26^{\mathrm{Ba}}$ & $99.00 \pm 0.03^{\mathrm{Bb}}$ & $82.05 \pm 0.08^{\mathrm{Ba}}$ \\
\hline & 10 & $99.07 \pm 0.02^{\mathrm{Cb}}$ & $99.72 \pm 0.05^{\mathrm{Bb}}$ & $90.98 \pm 0.15^{\mathrm{Ca}}$ \\
\hline \multirow{3}{*}{ Clothianidin } & 2 & $88.17 \pm 0.06^{\mathrm{Ab}}$ & $67.24 \pm 6.92^{\mathrm{Ab}}$ & $66.32 \pm 2.87^{\text {Аа }}$ \\
\hline & 5 & $98.45 \pm 0.02^{\mathrm{Ba}}$ & $96.91 \pm 0.58^{\mathrm{Ba}}$ & $93.12 \pm 0.86^{\mathrm{Ba}}$ \\
\hline & 10 & $99.08 \pm 0.02^{\mathrm{Ba}}$ & $99.16 \pm 0.04^{\mathrm{Ba}}$ & $99.16 \pm 0.46^{\mathrm{Ba}}$ \\
\hline \multirow{3}{*}{ Thiamethoxam } & 2 & $71.15 \pm 1.85^{\mathrm{Aa}}$ & $61.46 \pm 1.06^{\mathrm{Aa}}$ & $61.44 \pm 0.40^{\mathrm{Aa}}$ \\
\hline & 5 & $85.36 \pm 0.23^{\mathrm{Ba}}$ & $81.44 \pm 0.02^{\mathrm{Ba}}$ & $79.00 \pm 0.03^{\mathrm{Ba}}$ \\
\hline & 10 & $97.50 \pm 0.07^{\mathrm{Ca}}$ & $92.76 \pm 0.03^{\mathrm{Ca}}$ & $92.79 \pm 0.12^{\mathrm{Ca}}$ \\
\hline \multirow{3}{*}{ Thiacloprid } & 2 & $1.4 \pm 1.07^{\mathrm{Aa}}$ & $1.6 \pm 1.03^{\mathrm{Aa}}$ & $0.80 \pm 0.23^{\mathrm{Aa}}$ \\
\hline & 6 & $2.6 \pm 1.14^{\mathrm{Ba}}$ & $0.43 \pm 0.13^{\mathrm{Aa}}$ & $1.41 \pm 1.85^{\mathrm{Aa}}$ \\
\hline & 10 & $2.6 \pm 0.20^{\mathrm{Ba}}$ & $0.47 \pm 0.37^{\mathrm{Aa}}$ & $2.07 \pm 0.12^{\mathrm{Aa}}$ \\
\hline Acetamiprid & 20 & $0.22 \pm 0.01^{\mathrm{a}}$ & nd & $1.28 \pm 0.18^{\mathrm{b}}$ \\
\hline
\end{tabular}

a, data expressed as the means $\pm \mathrm{SE}$ of triplicate experiments. For a specific pesticide, different letters in a column are shown in uppercase $(\mathrm{A}-\mathrm{C})$ or in a row in lower case $(\mathrm{a}-\mathrm{c})$, indicating a statistically significant difference $(\mathrm{P}<0.05)$; nd, not detected.

water and $1.28 \%$ in $\mathrm{pH} 6.5$ buffer; toxicity tests were also not completed for acetamiprid.

Thiacloprid and acetamiprid pesticides are not persistent in the environment because of a high water solubility (the water solubility and $\log$ octanol-water partition coefficient $\left(\log \mathrm{K}_{\mathrm{OW}}\right)$ of the active ingredient at $20{ }^{\circ} \mathrm{C}$ is $185 \mathrm{mg} \mathrm{kg}^{-1}$ and 1.26 , respectively), resulting in the potential contamination of surface water following rainfall
(EPA 2003). Krohn \& Hellpointner (2002) reported that thiacloprid was stable in water between $\mathrm{pH}$ 5.0 and 9.0 for a relatively long period of time. Acetamiprid is relatively non-persistent and although it is mobile, rapid degradation will reduce its potential to leach to groundwater. Pitam et al (2013) reported that acetamiprid is stable in acidic and neutral conditions compared to alkaline conditions. The stability of thiacloprid and 
acetamiprid in water was also indicated elsewhere (EPA 2002; 2003; Cernigoj 2007), so it is important to develop a successful method for thiacloprid and acetamiprid degradation.

\subsection{Clothianidin and thiamethoxam degradation by ozone treatment}

Two and 5 minutes of ozone treatment reduced the clothianidin content $88 \%$ and $98 \%$, respectively. Extending the treatment time from $5 \mathrm{~min}$ to 10 min had no effect on clothianidin degradation in water. The degradation rates were 71 and $85 \%$ for thiamethoxam at 5 and $10 \mathrm{~min}$, respectively (Table 3) (Figure 1). Therefore, 2 minutes of ozone treatment yielded a significant reduction for both of these two pesticides and no extended treatment times were needed. However, ozone treatment increased the toxicity for these two pesticides (Table 4) because of the formation of new compounds. The degradation products of thiamethoxam were considerably (approximately 2.7 times) more toxic than the original compound. The toxicity experiments on these two pesticides were repeated numerous times and the same results were always obtained. As indicated by Hwang et al (2002), the degradation products may have a higher toxicity than the active ingredients themselves. Thus, "the risk from pesticides in the diet cannot be completely removed by ozonation" unless the breakdown products are proven safe (Karaca \& Velioglu, 2007). Degradation of clothianidin and thiamethoxam by ozone cannot be recommended because of the higher toxicity of the degradation products.

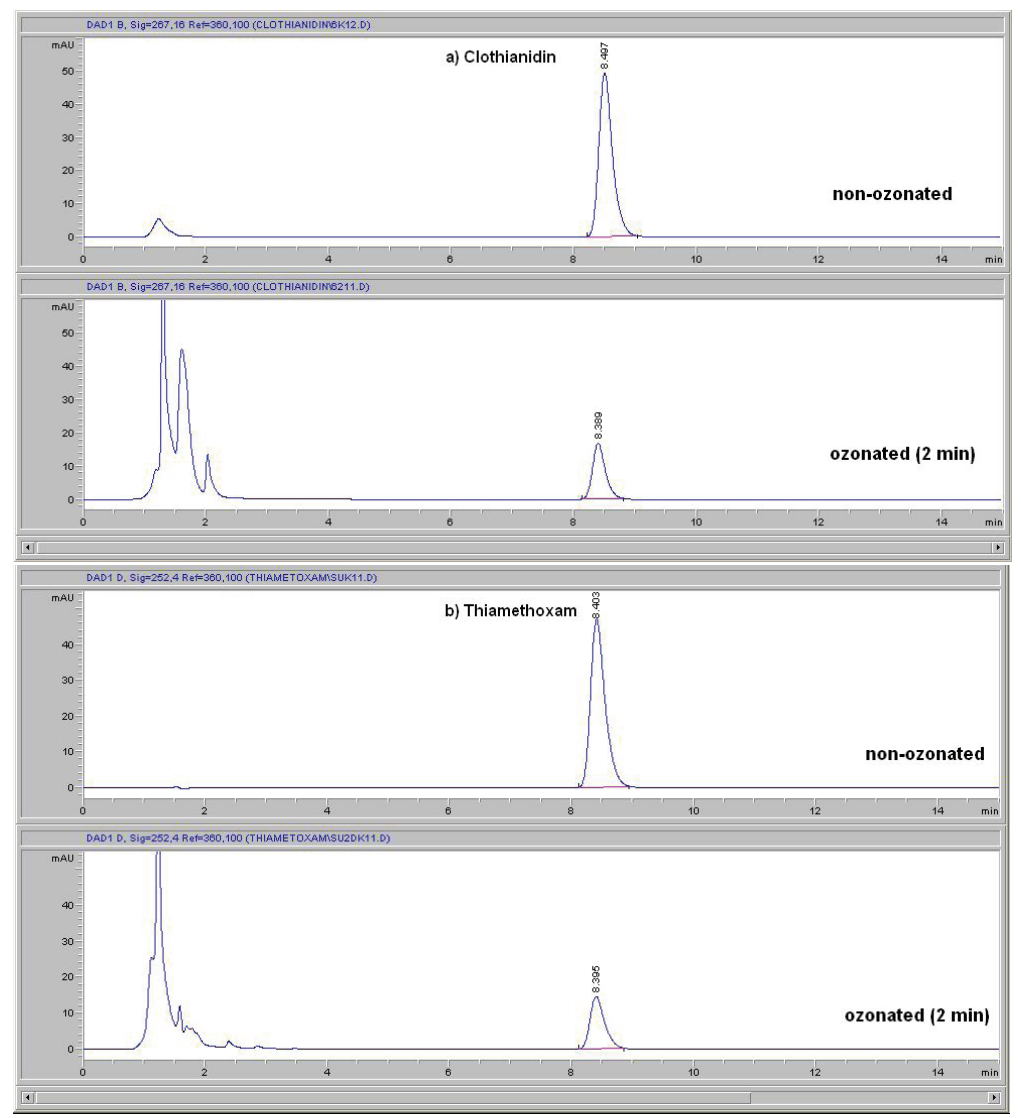

Figure 1- Effects of ozone treatment on the degradation of clothianidin (a) and thiamethoxam (b) 
Table 4- The effects of ozonation on the acute pesticide toxicity on Daphnia magna (48 hours, $20 \mathrm{~mL}$ )

\begin{tabular}{|c|c|c|c|c|c|}
\hline \multirow[b]{2}{*}{ Pesticides } & \multicolumn{2}{|c|}{$L C_{50}\left(\mu \mathrm{g} \mathrm{L}^{-1}\right)$} & \multirow{2}{*}{$\begin{array}{c}\text { Toxicity reduction } \\
\text { coefficient by } \\
\text { ozonation }\end{array}$} & \multirow{2}{*}{$\begin{array}{c}\text { Ozonation } \\
\text { time } \\
\text { (sec) }\end{array}$} & \multirow{2}{*}{$\begin{array}{c}\text { Ozonated pesticide } \\
\text { concentration }\left(\mathrm{mg} \mathrm{L}^{-1}\right)\end{array}$} \\
\hline & Non-ozonated & Ozonated & & & \\
\hline Fenazaquin & 1623 & 14662 & 9.03 & 60 & 10 \\
\hline Lambda cyhalothrin & 0.003 & 0.010 & 3.33 & 120 & 10 \\
\hline Azoxystrobin & 88317 & 197258 & 2.23 & 120 & 80 \\
\hline Chlorpyrifos & 0.220 & 1.037 & 4.70 & 30 & 10 \\
\hline Spiromesifen & 1338 & 1954 & 1.46 & 1200 & 50 \\
\hline Clothianidin & 132403 & 120000 & increased toxicity & 120 & 100 \\
\hline Thiamethoxam & 213316 & 77868 & increased toxicity & 300 & 100 \\
\hline Thiacloprid & \multicolumn{5}{|c|}{ Very low degradation by ozone. Toxicity experiments were not performed. } \\
\hline Acetamiprid & \multicolumn{5}{|c|}{ Very low degradation by ozone. Toxicity experiments were not performed. } \\
\hline
\end{tabular}

3.3. Fenazaquin, lambda cyhalothrin, azoxystrobin, chlorpyrifos and spiromesifen degradation by ozone treatment

Fenazaquin, lambda cyhalothrin, azoxystrobin, chlorpyrifos and spiromesifen (Figure 2) were perfectly degraded with the application of ozone (Table 3). Degradation rates in 5-min ozonated samples in water solutions were between 87 and $99 \%$ for all of the five pesticides. Even 2 minutes of treatment time yielded $>90 \%$ degradation of all pesticides, except for spiromesifen (approximately 77\%).

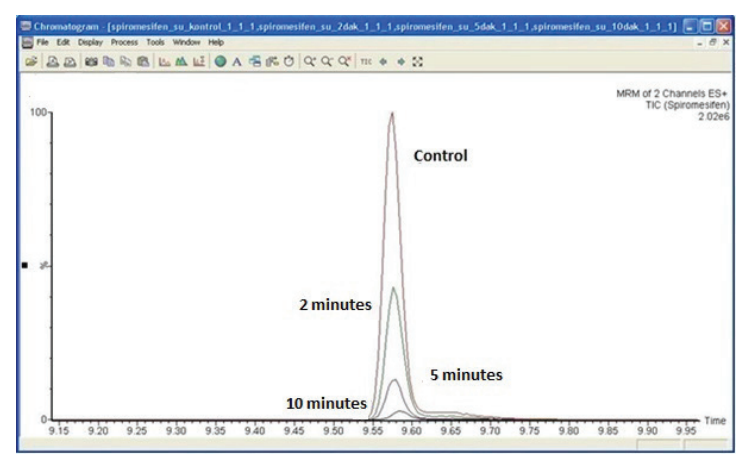

Figure 2- A sample LC-MS/MS chromatogram for spiromesifen degradation using ozone

When considering $5 \mathrm{~min}$ of treatment time, changing the ozonation media from water to a buffer solution did not significantly change the degradation rates of fenazaquin and lambda cyhalothrin. The use of a buffer revealed some changes on the other three pesticides; however, in all samples, the degradation rates were more than $80 \%$ (except in chlorpyrifos, which was $72 \%$ at a $\mathrm{pH} 5.5$ buffer). This finding indicates that these pesticides can be successfully degraded by ozone without the need of buffer use. Ozone treatment also significantly reduced the toxicity. Reduction rates varied between 1.46 and 9.03 times depending on the pesticide tested. The degradation mechanism of azoxystrobin was probably based on a hydroxyl radical attack (Calza et al 2006; Lofrano et al 2010). This study indicated that azoxystrobin was more prone to degradation under ozone conditions than other methods (UV, photo catalytic process, etc.) (Calza et al 2006). In contrast to our study, Lozowicka et al (2014) reported that only $48.9 \%$ of azoxystrobin decomposed in 5 min in their ozonation study.

\section{Conclusions}

Ozone is a strong oxidizing agent and can degrade some pesticides successfully. Among the nine pesticides tested in this study, thiacloprid and acetamiprid can only be degraded to an insignificant extent (max 2.6\%). Clothianidin and thiamethoxam can be easily degraded by ozone; however, their degradation products were found to be more toxic than the initial products. Other pesticides, namely, 
fenazaquin, lambda cyhalothrin, azoxystrobin, chlorpyrifos and spiromesifen, were easily degraded by ozone, and their toxicities were significantly reduced. It seems that chemical composition is a more significant factor than the chemical group on the degradation rate and toxicity. Thiacloprid, acetamiprid, clothianidin and thiamethoxam all belong to the same chemical group (neonicotinoids); however, the first two pesticides were not degraded by ozone, and the latter two were degraded easily. When investigating pesticide degradation by ozone, the toxicity of some degradation products must be seriously considered because of their higher toxicity, as shown in this study.

\section{Acknowledgements}

The authors wish to thank TÜBİTAK (The Scientific and Technological Research Council of Turkey) for their financial support (Project no. 110 O 201) and Dr. Sevilay KIRIS for her assistance with the spiromesifen analysis using LC-MS/MS.

\section{References}

Albanis T A, Hela D G, Sakellarides T M \& Konstantinou I K (1998). Monitoring of pesticide residues and their metabolites in surface and underground waters of Imathia (N. Greece) by means of solid-phase extraction disks and gas chromatography. Journal of Chromatography A 823: 59-71

Bajwa U \& Sandhu S (2014). Effect of handling and processing on pesticide residues in food- a review. Journal of Food Science and Technology 51: 201-220

Calza P, Medana C, Baiocchi C \& Pelizzetti E (2006). Light-induced transformations of fungicides on titanium dioxide: pathways and by-products evaluation using the LC-MS technique. International Journal of Environmental Analytical Chemistry 86: 265-275

Cernigoj U (2007). Photodegradation of organic pollutants in aqueous solutions catalyzed by immobilized titanium dioxide: Novel routes towards higher efficiency. University of Nova Gorica Graduate School, Dissertation

Chen J Y, Lin J Y \& Kuo W C (2013). Pesticide residue removal from vegetables by ozonation. Journal of Food Engineering 114: 404-411
EPA Environmental Protection Agency (2002). Acetamiprid; Reason for Issuance: Conditional Registration. http://www3.epa.gov/pesticides/chem search/ reg_actions/registration/f s_PC-099050_15Mar-02.pdf

EPA Environmental Protection Agency (2003). Pesticide fact sheet, thiacloprid. http:/www3.epa.gov/pesticides/ chem_search/reg_actions/registration/fs_PC-014019 26-Sep-03.pdf

Fikirdeşici Ş, Altındağ A \& Özdemir E (2012). Investigation of acute toxicity of cadmium-arsenic mixtures to Daphnia magna with toxic units approach. Turkish Journal of Zoology 36: 543-550

Horvitz S \& Cantalejo M J (2014). Application of ozone for the postharvest treatment of fruits and vegetables. Critical Reviews in Food Science and Nutrition 54: 312-339

Hwang E S, Cash J N \& Zabik M J (2001). Ozone and hydrogen peroxyacetic acid treatment to reduce or remove EBDCs and ETU residues in a solution. Journal of Agricultural and Food Chemistry 49: 5689-5694

Hwang E S, Cash, J N \& Zabik M J (2002). Degradation of mancozeb and ethylenethiourea in apples due to postharvest treatments and processing. Journal of Food Science 67: 3295-3300

Ikeura H, Kobayashi F \& Tamaki M (2013). Ozone microbubble treatment at various water temperatures for the removal of residual pesticides with negligible effects on the physical properties of lettuce and cherry tomatoes. Journal of Food Science 78: T350-T355

Karaca H \& Velioglu Y S (2007). Ozone applications in fruit and vegetable processing. Food Reviews International 23: 91-106

Karaca H, Velioglu Y S \& Nas S (2010). Mycotoxins: contamination of dried fruits and degradation by ozone. Toxin Reviews 29: 51-59

Karaca H, Walse S S \& Smilanick J L (2012). Effect of continuous $0.3 \mu \mathrm{L} / \mathrm{L}$ gaseous ozone exposure on fungicide residues on table grape berries. Postharvest Biology and Technology 64: 154-159

Kırıș S \& Velioglu Y S (2016). Reduction in pesticide residue levels in olives by ozonated tap water treatments and their transfer into olive oil. Food Additives \& Contaminants: Part A 33: 128-136

Kim S D, Kim I D, Park M Z \& Lee Y G (2000). Effect of ozone water on pesticide-residual contents of soybean 
sprouts during cultivation. Korean Society of Food Science and Technology 32: 277-283

Krohn J \& Hellpointner E (2002). Environmental fate of imidacloprid. Pflanzenschutz-Nachrichten Bayer 55: 3-25

Kusvuran E, Yildirim D, Mavruk F \& Ceyhan M (2012). Removal of chloropyrifos ethyl, tetradifon and chlorothalonil pesticide residues from citrus by using ozone. Journal of Hazardous Materials 241: 287-300

Lin L, Xie M, Liang Y, He Y, Chan G Y S \& Luan T (2012). Degradation of cypermethrin, malathion and dichlorovos in water and on tea leaves with $\mathrm{O}_{3} / \mathrm{UV} /$ $\mathrm{TiO}_{2}$ treatment. Food Control 28: 374-379

Lofrano G, Meric S \& Belgiorno V (2010). Tannery wastewater treatment by advanced oxidation processes. In Belgiorno V, Naddeo V \& Rizzo L, ed. Water, Wastewater and Soil Treatment by Advanced Oxidation Processes (AOPS). Ater Onlus, Salerno, Italy, pp. 197-217

Lozowicka B, Jankowska M \& Rutkowska E (2014). Investigations on fungicide removal from broccoli by various processing methods. Desalination and Water Treatment 57: 1564-1572

Martins J, Teles L O \& Vasconcelos V (2007). Assays with Daphnia magna and Danio rerio as alert systems in aquatic toxicology. Environment International 33: 414-425

Ong K C, Cash J N, Zabik M J, Siddiq M \& Jones A L (1996). Chlorine and ozone washes for pesticide removal from apples and processed apple sauce. Food Chemistry 55: 153-160

Pitam S, Mukherjee I \& Kumar A (2013). Evaluation of environmental fate of acetamiprid in the laboratory. Environmental Monitoring and Assessment 185: 2807-2816

Sanchez-Bayo F \& Goka K (2006). Ecological effects of the insecticide imidacloprid and a pollutant from antidandruff shampoo in experimental rice fields. Environmental Toxicology and Chemistry 25: 16771687

Wu J, Luan T, Lan C, Lo T W H \& Chan G Y S (2007). Removal of residual pesticides on vegetable using ozonated water. Food Control 18: 466-472 